Vol. 4, No. 2, 2017

https://doi.org/10.23939/eem2017.02.001

UDC 368

\author{
R. Dankiewicz \\ Phd, Assistant Professor \\ Rzeszow University of Technology (Poland)
}

\title{
THE ROLE OF MERCHANT CREDIT INSURANCE IN PROCESSES STIMULATING THE ECONOMIC SECURITY OF COMPANIES
}

\begin{abstract}
In the paper an attempt to present the role of merchant credit insurance in processes that affect the security of business operations of companies has been taken. As a part of the discussion, the areas and sources of the risks have been presented, their overall distribution has been taken into account, and particular attention has been paid to those that could be covered under insurance contracts concluded with credit insurers. The reasons underlying their use have been discussed, taking into account both the specificity of the risk and the benefits of its protection. In the practical part, the results of author's own research and the conclusions drawn have been presented. The final part of the paper contains conclusions on an attempt to assess the economic viability of merchant credit insurance in the activities of individual companies taking into account the external market conditions in which they operate.
\end{abstract}

Keywords: credit insurance, risk management

\section{Introduction}

The level of knowledge and opportunities concerning the management peculiarity of various risk types are significantly improving over time both for individuals, entire societies or economic entities. The evolution of the phenomenon makes us conclude that we should not aim solely at the elimination of risk, but to its management. Losses the company is incurred from the environment and the losses to which an enterprise exposes itself by its decisions determine the extent of its risk ${ }^{1}$, which has a significant impact on the level of its economic security. Therefore, it is necessary to

1 M. Kuchlewska, Ubezpieczenie jako metoda finansowania ryzyka przedsiębiorstw, Wydawnictwo AE, Poznań 2003, p. 40. seek comprehensive protection of the interests of the enterprise in all areas where it may be exposed to the negative consequences of risk implementation. One of the key areas that should be covered is the risk of non-payment for sold products or services rendered under deferred payment terms.

The purpose of this paper is to attempt to assess the role and importance of merchant credit insurance in the processes that stimulate economic security of enterprises in the area of receivables loss.

\section{Areas and sources of risk in companies operations}

Future situations are influenced by a large number of variables. It is possible to try to divide them into those that are at least partially identifiable, and into those in which such attempts are ineffective. Difficulties in this field are the cause of the occurrence of a risk phenomenon, which may result in damage. Its origins can be inherent in natural processes, but this is not always the case. Very often they are the result of intentional, conscious activity of people but may also be unintended, being a byproduct of the action addressed to another purpose. In the case of natural changes that occur without human intervention their prediction generally does not cause any major difficulties. The opposite situation occurs in the case of human activity, which often causes sudden transformations in the economic environment, manifested through the so-called progress variables. They include: population growth, 


\section{R. Dankiewicz}

education and training, accumulation, technical progress and innovation, geographic discoveries, changes in human needs and the ways in which they are met, as well as the international situation. The rapid pace of development of science and technology, shaping the relationship of production, increasing the size and importance of risk and spreading its manifestations, is what counts on the decision-makers and the actions that come with it $^{2}$. Each and every one should strive for the risk to be more predictable. One cannot avoid it, but one can manage it ${ }^{3}$.

Therefore, it is important for every entity to be aware of the possibility of realizing the risk of a consequence that could be its direct and indirect loss. Direct effects are usually visible quickly and can be measured, but indirect ones can unfortunately be revealed at different times. The array of dangers is broad and covers not only such common occurrences as theft of valuable equipment or attractive goods from warehouses, factory hall fire, destruction of buildings by flood or hurricane. The losses from these causes are very serious, but this is only a small part of the company's possible losses. Equally, the consequences of the implementation of financial risks, which cannot be clearly defined, are not more important. These risks are associated with any event that adversely affects an entity's ability to achieve its objectives or strategy or whether it is a measurable probability of loss or less than expected returns ${ }^{4}$. Proper identification and risk assessment gives it an opportunity to integrate it into the business management process. In addition, its capture requires consideration of potential consequences of its implementation, which may hinder achievement of the objectives set. These risks are more and more often associated with random events, but may result from decisions and actions that are not random, i.e. those that are independent of the will,

${ }^{2}$ B. Nietyksza, Zasady kompensowania szkód z tytułu ryzyka, PWE, Warszawa 1971, p. 26.

3 D. Laster, Every One is a Risk Manager, [in:] P. Shimpi (ed.) ,Integrating Corporate Risk Management, Texere LLC., New York 2000, p. 16.

${ }^{4}$ A. J. McNeil, R. Frey, P. Embrechts, Quantitative Risk Management: Concepts, Techniques and Tools, Princeton University Press, 2015, s. 3. knowledge, care and general psychophysical efficiency of the person. Losses are then unfavorable changes in the company's financial flows, i.e. deviations from the expected value of the company in the direction less than expected. They often run out in the future, which makes collecting information about them generally impossible or very difficult, as is the case of risk of receivables loss.

\section{Risk of receivables loss}

The pressure that the company faces in terms of resource constraints and market demands imposes the need to make money, which results in the emergence of risks that are manifested through threats that may prevent achievement of the intended objectives. In the market economy companies are facing increasing competition and constant volatility of external conditions. In order to meet these conditions they increasingly decide to liberalize delivery conditions, which results in an extension of the collection period. The higher the range of freezing of receivables, the greater is the probability of the cost of lost opportunities and, at the same time, the lower return on capital. This is a commonly occurring risk at present, whose essence is that the borrower cannot or does not want to meet the commitment made at the time of the transaction. This phenomenon was especially exposed by the financial crisis of 2007-2010, then many OECD companies operating on the grounds of lack of insurance claims went bankrupt, many units reduced sales, which was their way to manage risk. In this way, a spiral of problems coincided, as a result of which the banks reduced funding for companies without adequate insurance coverage ${ }^{5}$. As a result, there were observed several trends in the insurance market that resulted in increased demand for policies, the identification of underserved markets, increased competition and growing concerns over increasing risks. It was noted that active observation and assessment of market conditions and indicators were crucial in

5 The Impact of The Financial Crisis on The Insurance Sector and Policy Responses, OECD Publishing, 2011, no. 13, pp. 30-31. 
minimizing negative impact of economic fluctuations in the economy. Proactive and meticulous management based on the state of the economy can mitigate the impact of business cycles ${ }^{6}$.

Sometimes receivables from customers are a significant part of assets. Without paying attention and taking security measures, the business will never be fully secure. This is confirmed by studies conducted, among others, in Poland each year the so-called bad debts in about $20 \%$ are a direct cause of business insolvency (similar situation occurs in Western Europe). This is shocking if one takes into account the relatively high popularity of merchant credit insurance or other forms of payment security in the region.

Contracts concluded, despite the detailed specification of the obligations of the parties, contractual penalties for breach of contractual obligations and the manner of settlement of disputes, do not provide reasonable assurance of the legitimate interests of counterparties. Frequently, the specific nature of the transaction makes it impossible to identify possible commercial weaknesses during the execution of the contract, and in many cases they are revealed after the contract had been completed. Undoubtedly, credit risk is the most widespread in the era of corporate lending not only from financial institutions but also from trading partners. In practice, however, under the concept of credit there are many variants of it: financial, merchant, advance, commitment or trust. However, there is no one and at the same time exhaustive classification in this regard, while its creation seems very difficult, but also pointless. From a business practice perspective it is important to distinguish between the risks that can be insured and those whose insurers are not willing to accept. From a theoretical point of view, an insurance company is able to cover any type of risk insurance coverage. Due to the scope of the study, the consideration will be limited to the risk of loss of receivables secured by credit insurance, which, according to Swiss Re assumptions has been classified as financial risk? This risk can be defined as a

6 E. Clipici, Credit Insurance During the Financial Crisis, Practical Application of Science, 2013, vol. 1, no. 1, 43-44.

${ }^{7}$ Credit and Bonding Reinsurance, Swiss Insurance Training Center, Swiss Reinsurance Company 1986. numerical value characterizing the ability of a given counterparty to meet its obligations ${ }^{8}$. The source of information about credit risk may be the ones who are interested in insurance as well as other entities with whom the cooperation is conducted. An entity, whose obligations are insured, does not necessarily need to know that. It becomes necessary to gather a lot of information including financial data, information about an owner, references and opinions, information on the entity's history, about the business, the information that describe the organization of the company and the existing cooperation with both suppliers and recipients. Additional sources may be registers which are intended to ensure transparency and security of circulation. Acquisition and processing of customer information is a quest to equalize the opportunity in a game called "customer risk assessment" by completing missing data or drawing conclusions from the data already available $^{9}$. Information obtained from many sources allows an insurer to recognize, assess and monitor credit risk.

\section{Credit insurance in the process of managing the risk of receivables loss \\ The functioning of enterprises in the} market environment creates the flow of business between companies, accompanied by specific risks of delays in supply, poor quality of products or services, and particularly delays or lack of payment. The pursuit of profit maximization has necessitated the need for professional, planned and organized diagnosis and countermeasures arising from the realization of the various risks within the risk management processes within the individual stages ascribed to them, including credit risk. Integrated risk management is becoming increasingly popular, mainly because of the promotion of academics, credit rating agencies and state institutions ${ }^{10}$.

\footnotetext{
${ }^{8}$ M. Sierpińska, D. Wędzki, Zarządzanie płynnościq finansowa przedsiębiorstwie, PWN, Warszawa 1997, p. 149.

9 M. Wyżycki, D. Pałczyński, Źródła informacji dla oceny ryzyka kredytowego, [w:] Ryzyko kredytowe wierzytelności hipoteczne. Modelowanie i zarządzanie, red. K. Jajuga, Z. Krysiak, Związek Banków Polskich, Warszawa 2004, s. 38.

${ }^{10} \mathrm{P}$. Bromiley, M. McShane, A. Nair, E. Rustambekov, Enterprise Risk Management: Review, CritiQue, and Research Directions, Long Range Planning, no. 48, s. 265.
} 


\section{R. Dankiewicz}

- In the case of business activity, credit risk is practically unavoidable. With this type of transaction we have to deal with each other in relation to the parties to a legal relationship, each of whom is supposed to fulfill the benefit of the other, and the dates of fulfillment of the benefits are different. As a result one side of the relationship must previously provide for the other and then expect the other's mutual benefit. The credit insurance contract is of the highest trust, it is based on the reliability and completeness of the information provided by the parties and their full cooperation during the insurance period. The information that underlies the risk assessment is not generally public and available. In addition to hedging the insurer puts emphasis on introducing procedures to minimize risk. Most often they come down to the following of the conditions during the term of the insurance contract by the insured, in which he is obliged to transfer certain information to the insurer. When risk-taking measures prove ineffective, properly prepared and undertaken actions imposed by the insurer should lead to a reduction in the magnitude of the damage and avoid further, sometimes even greater damage. It can be said that they constitute an emergency plan covering direct procedures at the time of the occurrence of the event giving rise to the damage, the directions of the activities enabling the continuation of normal operations and the procedures to restore the situation before the occurrence of the injury. The introduction of a credit risk analysis and monitoring system offers additional benefits ${ }^{11}$ :

management;

- facilitates control of receivables

- reduces staff training costs and erroneous credit decisions;

- reduces the amount of bad debts and thus reduce the cost of capital;

- increases the amount of information about the business environment.

The characteristic of credit insurance is that the duration of an insurance contract, the expiration of which is in the case of a classical insurance policy, means the end of the liability of an

11 M. Sierpińska, D. Wędzki, Zarządzanie ptynnościa finansowa $w$ przedsiębiorstwie, Wydawnictwo Naukowe PWN, Warszawa 1998, p. 150. insurance company, the loan guarantee can only mean the end of the insurer's overdraft period, while its liability extends over the life of the loan. Since the parties to a credit transaction are not fulfilled at the same time, the entity which first satisfies them (the lender) is at risk of nonperformance by the other party. A diagram of the functioning of trade credit insurance covering the individual periods during the insurance contract is shown in Fig. 1.

Treating insurance as the only form of risk management that is an alternative to managing it is a wrong approach. On the contrary, all safety processes should be mutually complementary and, what is extremely important, the introduction of one element cannot loosen discipline from the other. It is in the interest of the company to prevent, which, on the one hand, reduces the likelihood of injury and, if the risk to which it is the consequence, is insured, leads to a reduction in the cost of insurance. In most cases, despite the fact that the risk is transferred to the insurer and so its part remains with the insured (own share, franchise). Awareness of the risk, which may result in a threat to the achievement of the target, makes the companies themselves interested in taking control actions that reduce the chance of realized risk, thereby allowing them to continue to operate.Research in the world confirms that there is a link between the volume of insured trade and the increase in sales, especially in exports. With a $1 \%$ higher level of insured export value contributes to an increase in the value of exports in general by $0.01 \%$. At the moment when the insured exports less than $1 \%, 5 \%$ and $10 \%$ of the insured exports, it turns out that every EUR involved in export credit insurance generates an average increase in exports by 1,3 EUR. From further observation it is clear that countries where the share of insured receivables is higher represent more trade than those in which insurances are rare. Thus, there is a strong positive statistical relationship confirming the impact of receivables insurance on export ${ }^{12}$.

12 J. M. Koen van der Veer, The Private Export Insurance Effect on Trade, The Journal of Risk and Insurance, 2015 , vo. 82 , no. 3, pp. 608-614. 

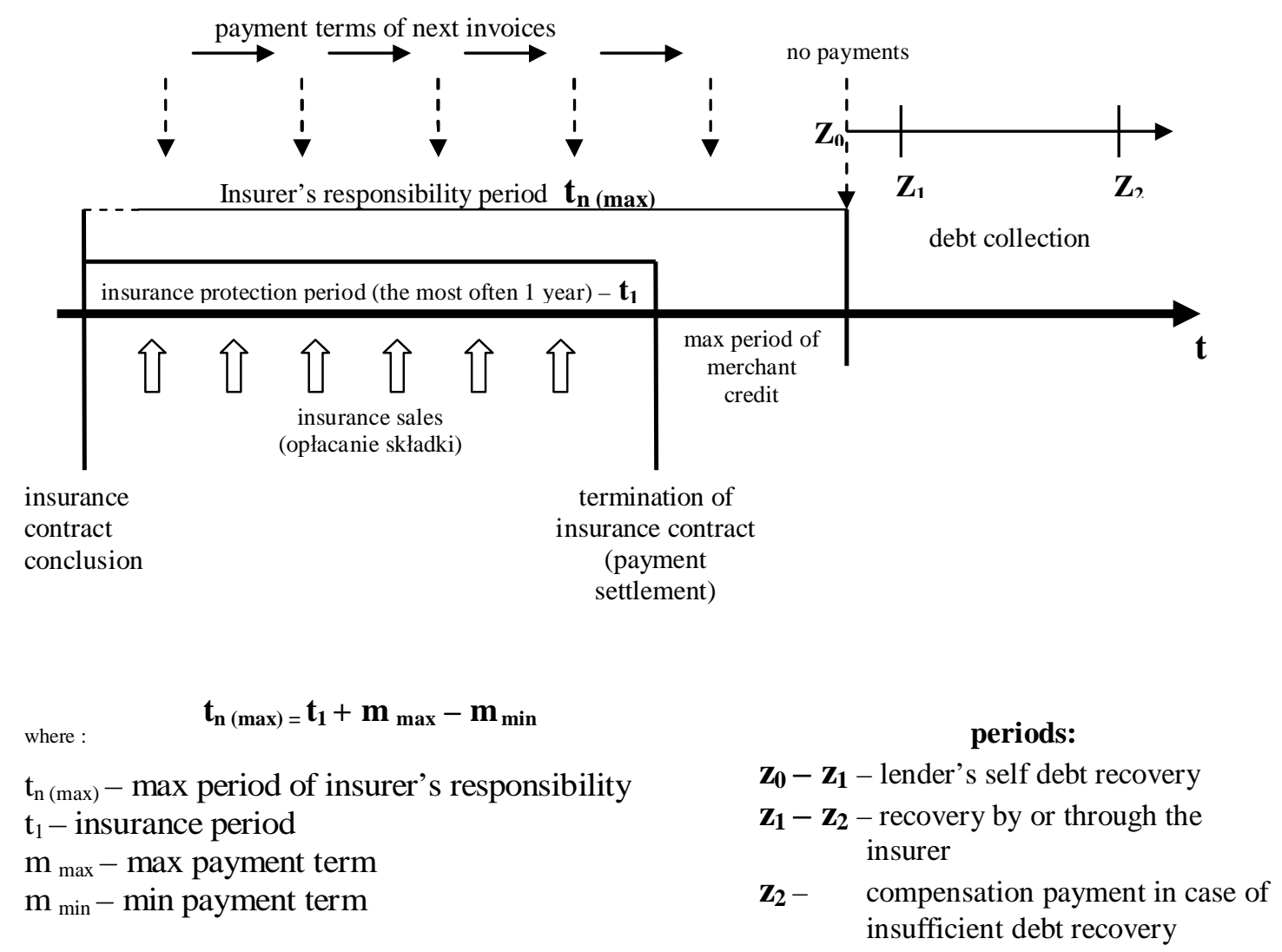

Fig. 1. Terms and time intervals used in merchant credit insurance.

Source: R. Dankiewicz, Przedziaty czasowe w ubezpieczeniu kredytu kupieckiego, [in:] ed. J. Handschke, Studia ubezpieczeniowe, ZN nr 127, Wyd. UE, Poznań 2009, p. 177.

\section{Merchant credit insurance in the light of own research}

In order to obtain empirical data on the role of the merchant credit in the processes that stimulate economic security of enterprises, a pilot study was conducted using a questionnaire and a direct interview was used as a technique of observation. The survey research was the most effective form of data collection, often inaccessible in no other way. Their use was explained by the ability to clarify possible complexities of the formulation and the speed of data acquisition.

The purpose of the study was to determine the role and significance of merchant credit insurance in the processes ensuring economic security of the audited entities. The surveyed population comprised 147 small, $14.3 \%$, medium $(72.8 \%)$ and large $(12.9 \%)$ respondents who responded to the questionnaire between January and March 2017. When comparing the results obtained with the data of a similar study carried out in 2005, there is a clear increase in interest in the offer of insurance companies on the part of entrepreneurs in the analyzed insurance. In the group of large entities, an interest in the offer increased from $19.5 \%$ to $63 \%$, in case of medium companies from $4.7 \%$ to $38 \%$, while in the case of small entities from $0 \%$ to $4.7 \%$. According to the declarations, the lack of interest of small entities results from the lack of an acceptable offer for this market segment. For most large and medium-sized companies decisions are made by the board of directors - $57 \%$ (29 entities), one by the president/owner - 19\% (10 entities) and the chief accountant $-24 \%$ (12 entities). As the main reasons for increasing interest in the insurer's offer within insuring commercial credit entrepreneurs provide: the need to secure against various types of risk $100 \%$, support in the assessment of recipients' financial liability $(90.2 \%)$, tradition within establishing the 


\section{R. Dankiewicz}

insurance agreements $(76.5 \%)$, less often the requirements of other market participants $(7.8 \%)$ and the law regulations (5.9\%).

The source of information on merchant credit insurance does not necessarily have to be insurance companies and their surroundings understood as different types of brokers. Paradoxically, the respondents may be contractors who, through specific requirements, influence the growth of insurance awareness and thus create demand for specific products offered by insurers. The main source of information is the insurance brokers' offer $-66.7 \%$, the insurance companies themselves $-51 \%$ and the information available on the market $47.1 \%$.

The most important factors influencing the quality of protection in the opinion of the respondents are: the reality of the protection provided, timely and correct settlement of losses, the level of financial coverage of losses, the speed of payment of compensation (the above may be a surprise, taking into account the specificity of credit insurance and compensation periods often exceeding 180 days from the date of notification damages). In the analyzed case, counseling on credit risk management and debt collection is of particular importance in all types of insurance. The scope of the offer is for companies to support their activity in the field of control. The insurer is not limited to making an insurance decision. Through additional services, he monitors the situation of creditors and warns them about their uncertain or threatened financial situation before signing a contract, thus warning them before contracting.

The surveyed group of respondents was asked whether in the past there were situations when the lack of trade credit insurance could disrupt the functioning of the company. The answer was not universal, although it could not be marginalized. The most common reasons for the disruption were the bankruptcy of the debtor and the loss of the contract. Failure to pay the invoice without other conditions that make it impossible to make a payment is a major concern for small businesses, although it affects all parties to a large extent regardless of their size. This phenomenon in the opinion of the representatives of the investigated entities in many cases negatively affect their functioning.
Examining the effectiveness of insurance coverage, if it is to be effective, should be carried out from the policyholder's point of view, i.e. from the one who directly sees the effectiveness of insurance coverage at the time of the insurance accident. The most important issue for him is obtaining full compensation $^{13}$ (in the case of commercial credit insurance, the amount of compensation paid is reduced by the obligatory contribution of the insured person) and the certainty that in the event of a particular accident, the compensation is fully real.

However, serious difficulties may arise when trying to express the effects that an entity achieves through the use of insurer's credit insurance services. The proposal for recognition as a result of the insurance business of the indemnity paid does not seem to be right. In addition, the insured's knowledge of the insurance company's readiness to cover losses, which at any moment can be translated into specific amounts resulting from lost receivables, should be recognized as an effect. This intangible effect cannot be expressed in terms of value. Similar problems are encountered by the surveyed entrepreneurs, despite the fact that they have concluded a receivables insurance policy, but they have problems with the exact size of the insured turnover and the final amount of premiums.

\section{Conclusions}

The previous reflections seem to lead to the conclusion that any study of efficacy should only refer to those human activities that are embodied in material goods, but in terms of services, including insurance, and in particular trade credit insurance, about testing their quality. Thus, the impact of insurance coverage on the effectiveness of the economy is determined by the quality of this protection, and thus the quality of the insurance services provided and the insurance coverage, i.e. the assessment of the entities with which the cooperation is conducted, assistance in debt collection or psychological effects. The number of claims depends on the economic situation, so it is not unusual that the amount of compensation paid

13 H. Poleszak, Pojęcie efektywności ochrony ubezpieczeniowej i metody jej oceny, Studia Ubezpieczeniowe, vol.VI, Warszawa-Poznań 1982, p. 59. 
in two consecutive years may vary widely and the amount of compensation paid differs from the amount of the loss, because insurers know that it will be difficult for them to recoup insurance to recover the entire payment arrears ${ }^{14}$. The final assessment of merchant credit insurance, taking into account all factors affecting its effectiveness, can only be made by reference to the interest of the individual undertakings, which may be the subject of separate considerations. The economic costeffectiveness of the insurance determines the result of the ratio of costs incurred to insurance against the effects of the insurer's activity in the newly created receivables structure, while taking into account the costs incurred so far.

\section{References}

1. Bromiley P., McShane M., Nair A., Rustambekov E. Enterprise Risk Management: Review, CritiQue, and Research Directions, Long Range Planning, no. 48 .

2. Clipici E., Credit Insurance During the Financial Crisis, Practical Application of Science, 2013, vol. 1, no. 1 .

3. Credit and Bonding Reinsurance, Swiss Insurance Training Center, Swiss Reinsurance Company 1986.
4. Dankiewicz R., Przedzialy czasowe w ubezpieczeniu kredytu kupieckiego, [in:] ed. J. Handschke, Studia ubezpieczeniowe, ZN nr 127, Wyd. UE, Poznań 2009.

5. Kuchlewska M., Ubezpieczenie jako metoda finansowania ryzyka przedsiębiorstw, Wydawnictwo AE, Poznań 2003.

6. Laster D., Every One is a Risk Manager, [in:] P. Shimpi (ed.) ,Integrating Corporate Risk Management, Texere LLC., New York 2000.

7. McNeil A.J., Frey R., Embrechts P., Quantitative Risk Management: Concepts, Techniques and Tools, Princeton University Press, 2015.

8. Nietyksza B., Zasady kompensowania szkód z tytułu ryzyka, PWE, Warszawa 1971.

9. Sierpińska M., Wędzki D., Zarzqudzanie płynnościa finansowq przedsiębiorstwie, PWN, Warszawa 1997.

10. Sierpińska M., Wędzki D., Zarzadzanie plynnościa finansowa $w$ przedsiębiorstwie, Wydawnictwo Naukowe PWN, Warszawa 1998, p. 150.

11. The Impact of The Financial Crisis on The Insurance Sector and Policy Responses, OECD Publishing, 2011, no. 13.

12. Wyżycki M., Patczyński D., Źródła informacji dla oceny ryzyka kredytowego, [w:] Ryzyko kredytowe wierzytelności hipoteczne. Modelowanie $i$ zarzadzanie, red. K. Jajuga, Z. Krysiak, Zwiazek Banków Polskich, Warszawa 2004.
${ }^{14}$ International Financial Consulting, Study on short - term trade finance and credit insurance In European Union, Publications Office of European Union, pp. 5-7. 